\title{
Effects of Problem-Based and Discovery-Based Instructional Strategies on Students' Academic Achievement in Chemistry
}

\author{
Joy Chinelo Anyafulude
}

\author{
Department of Educational Foundations, \\ Enugu State University of Science and Technology (ESUT), Enugu-Nigeria
}

\section{Doi:10.5901/jesr.2013.v3n6p105}

\begin{abstract}
The study investigated effect of Problem-based and Discovery-based instructional strategies on students' Achievement in Chemistry in Agbani Education Zone of Enugu State. The research adopted a quasi-experimental pre-test, post-test, non-equivalent control group design involving two experimental and one control groups. The sample comprised 375 senior secondary class two Chemistry students from three intact classes randomly drawn from a clustered sample of three senior secondary schools in Agbani Education Zone. The classes were assigned randomly to experimental and control groups. Experimental groups were taught selected topic in Chemistry using problem-based and discovery-based strategies. Control groups were taught the same topic using expository method. Pre-test was administered to both groups before the commencement of the treatment. Treatment was administered for a period of 6 weeks after which a post-test was administered. Data was collected using two instruments, pre and post-achievement tests in Chemistry duly validated and a reliability co-efficient of . 71 obtained using Kuder Richardson 20 (KR - 20) formular. Data were analyzed using mean and standard deviation to answer the research questions while analysis of Coveriance (ANCOVA) tested hypotheses at .05 significance level. It was revealed among others that problem-based strategy significantly enhanced students' achievement in Chemistry more than the discovery-based and the expository strategies.
\end{abstract}

Keywords: Problem-based, Discovery-based, Achievement, Gender, Chemistry

\section{Introduction}

Most nations develop because of the dominant role played by science. Science has been instrumental to the solution of the socio-economic problems facing nations like Nigeria. Such problems include hunger, unemployment and population explosion (Afolabi, 2009). However, Nigeria has been making frantic efforts to create scientific and technological awareness in her citizenry (Adeyemi, 2007).

All over the world, there has been an increasing search for means of improving and promoting teaching and learning especially the teaching and learning of Chemistry and other sciences. It is believed that this search will promote better understanding of science concepts and encourage greater scientific and technological advancements. This search has led to lots of research done by science educators towards making science education better, especially in the area of teaching students with the notion of discovering, engaging in critical thinking, questioning and developing problem solving skills. Therefore, the curriculum for science and technology should be developed to educate science - literate students to enable them inquire and solve problems facing them.

Many developed and developing countries of the world have introduced many educational reforms especially in the field of science and technology. Some countries like Japan, American and Britain have achieved good results and have become self reliant. Unfortunately Nigeria, despite all 
the reforms and innovations, such as the 6-3-3-4 system of education, the Universal Basic Education (UBE), the introduction of guidance and counseling in schools, expanded curriculum, for example, the study of introductory technology, not much success have been recorded. Science education has not succeeded in producing a self reliant nation. Teaching and learning of science, in particular Chemistry, in Nigerian schools has been criticized that it has often resulted in poor students' performance (Ivowi 1984, Otuka 1987, Okebukola and Jegede, 1986, all in Egbo 2004). These researchers identified a number of factors as being responsible for the observed trend. It is possible that those factors act singly or in combination affecting students' achievement. Such factors as identified by the researchers include students' poor academic background, insufficient qualified teachers, unmotivated teachers and students, inappropriate teaching and learning strategies and lack of innovative instructional strategies. The need to foster students' achievement in Chemistry has given rise to innovative approaches that provide room for students' active participation in the lesson.

Problem-based instructional strategy consists of carefully selected and designed problems that demand from the learner acquisition of critical knowledge, problem solving proficiency, self-directed learning strategies and team participation skills (Maloney, 2004). It reduces teacher's instruction where learners are seen as active listeners and passively involved in classroom activities as in the case of conventional method. Problem-based learning is an example of constructivist learning strategy which poses significant contextualized real world situations and provide resources, guidance, and instruction to learning as they develop content knowledge and problem solving skills (Yager, 2001).

The first task for the teacher in problem-based learning is to guide the students to identify the problems and help them to link with previous knowledge. The students discuss the problems cooperatively among themselves in a small group, explain what they know, pose research questions, generate hypotheses, develop initial plans and organize their knowledge, attempt to solve the problems with several modifications, derive learning goals and organize further work.

Finally, the results are presented to larger groups through the guidance of the teacher, instructor or facilitator and the students are allowed to reflect on the learning that has taken place. Problem-based learning is a form of inquiry-based learning which explains the environment in which learning is driven by a process of inquiry constructed by the students.

Discovery is a way from the unknown to the known by the learners themselves (Bruner, 1966). The active participation of the learner in the learning process is called discovery learning (Bruner, 1968; Kara \& Ozgun-Coca, 2004; Kipnis, 2005). In discovery learning, students construct knowledge based on new information and data collected are used by them in an explorative learning environment (De J ong \& Van Joolingen, 1998).

Bruner (1961) states that learning happens by discovering, which prioritizes reflection, thinking, experimenting, and exploring. Discovery instructional approach to education is more closely aligned with constructivist concepts of exploration, discovery and invention (Bok, 2006). Constructivist theory is the basis for discovery learning. Under both constructivism and discovery learning, educators subscribe to the idea that "knowledge cannot be transferred from one person to another" (Domin, 1999). Instead, a student needs to experience an event in order to make it truly meaningful. In a constructivist classroom, the role of the teacher is less defined. The teacher is no longer the focal point of the classroom. Instead, the would be instructor is now seen as a "facilitator, mentor, coach, or consultant" (Honebein, 2006). Additionally, the role and expectations of the students are transformed. Under constructivist theory, the emphasis is not on the amount of content that a student manages to retain, but is on the manner in which the students learn, or constructs knowledge (Honebein, 2006).

Over the years, the predominant method of instruction in schools has been the expository method (Nwabufo, 2005). By this method, learners were encouraged to master course content through constant repetition of facts and drills. The method guarantees the completion of the course outline on time, but incidentally encourages learners to memorize and regurgitate content of 
learning experiences instead of digesting and assimilating them. Most teachers in Nigerian schools use the expository method, which unfortunately provides little or no room for active student participation in the lesson. This expository (conventional) method of teaching has no laid down principles of learning.

Urevbu (1990) stated that the students' active participation in a lesson aids understanding and achievement. Jerkin and Dodds (2006) confirmed that statement when they said that schools are provided with curricular that have to be learnt and which are within the limits of the learner's own understanding. The teacher should deliver this using appropriate instructional strategies and relevant instructional materials to enable the learner achieve optimally. Obviously, when the teacher meaningfully imparts his lesson and allows active participation on the part of the students, there is bound to be high degree of achievement ability and also improved performance.

The social milieu, aspirations and rewards for males and females in our society also have some effects on their respective intellectual development. The reluctance of hardwork of the majority of females in our society should have some effects on their respective intellectual development. Hence, girls differ from boys in the age at which they develop logical thinking (Piaget, 1965).

The aim of the present study was therefore, to discover an instructional strategy that will result to better achievement in male and female students in Chemistry subject. There is therefore the need to determine the effect of problem-based and discovery-based instructional strategies on students' achievement in chemistry.

\section{Purpose of the Study}

The study sought to determine the effect of problem-based and discovery-based instructional strategies on the achievement of students in Chemistry. Also, the study sought to ascertain the influence of gender on students' achievement in Chemistry.

\section{Research Questions}

The following research questions guided the study.

1) What are the differences in the mean achievement scores of students taught with discovery-based, problem-based and expository instructional strategies?

2) What is the relative mean achievement score difference between the male and female students in the Chemistry post-test?

\section{Hypotheses}

The following hypotheses were tested at 0.05 level of significance.

1) There are no significant differences among the mean achievement scores of students taught with discovering-based, problem-based and expository instructional strategies.

2) There is no significant difference between the mean achievement scores of male and female students in post-treatment chemistry test.

\section{Research Method}

The study adopted a quasi-experimental pre-test, post-test, non-equivalent control group design involving two experimental and one control groups. The sample comprised 375 senior secondary class two (SS II) Chemistry students from three intact classes randomly drawn from a clustered sample of three senior secondary schools in Agbani Education Zone.

The data was collected using two instruments, the pre-achievement test in Chemistry and post-achievement test in Chemistry which were duly validated by three research experts. The 
regular Chemistry teacher subjected the experimental groups to instruction on chemical equilibrium using discovery-based and problem-based instructional strategies while the control group was taught using expository (conventional) strategy. The pre-test was administered to all groups (experimental and control groups) before the commencement of the treatment. Treatment was administered for a period of 6 weeks after which a post- achievement test in chemistry was administered to the subjects. The test re-test technique was used to determine the reliability coefficient of the instrument and the reliability co-efficient of 0.71 was obtained. Data collected were analyzed using mean, standard deviation and analysis of covariance (ANCOVA). Specifically, mean and standard deviation were used to answer the research questions while ANCOVA was used to test the hypotheses at .05 level of significance.

\section{Results}

\subsection{Research Question One}

What are the differences in the mean achievement scores of students taught with discovery-based, problem-based and expository instructional strategies?

Table 1: Relative Mean Scores of students taught with discovery-based, problem-based and expository instructional strategies in chemistry post-test?

\begin{tabular}{|l|c|c|c|}
\hline \multicolumn{1}{|c|}{ Groups } & $\bar{X}$ & SD & Cases $(\mathrm{n})$ \\
\hline Discovery-based strategy & 14.14 & 3.98 & 120 \\
\hline Problem-based strategy & 17.51 & 4.45 & 112 \\
\hline Expository strategy & 14.29 & 3.65 & 143 \\
\hline Overall & 15.31 & 4.42 & 375 \\
\hline
\end{tabular}

Table 1 above shows that mean scores of student taught using discovery-based instructional strategy was 14.14 with standard deviation of 3.98. The table also shows that the mean score of students taught the same topic using problem-based instructional strategy was 17.51 with standard deviation of 4.45 . Students taught with expository (conventional) strategy had mean score of 14.29 and standard deviation of 3.65 .

Generally, the results, as shown in table 1, indicate that the highest mean score was recorded by students taught with the problem-based strategy followed by that of students taught with the expository instructional strategy. The least mean score was obtained by students taught with discovery-based strategy. However, the standard deviations of students' scores in the chemistry post-test for discovery-based, problem-based and expository instructional strategy are 3.98, 4.45, and 3.65 respectively. Thus, there are more extreme scores in the problem-based group (SD = 4.45) than in the discovery-based group (SD = 3.98). The least standard deviation (3.65) was obtained for students taught with expository method indicating that the students' individual scores were more clustered around the mean than is the case with discovery and problem-based strategies.

\subsection{Research Question Two}

What is the relative mean achievement score difference between male and female students in the chemistry post-test. 
Table 2: Achievement scores of male and female students on the chemistry post-test.

\begin{tabular}{|c|c|c|c|}
\hline Sex & $X$ & SD & Cases $(n)$ \\
\hline Male & 13.51 & 4.00 & 174 \\
\hline Female & 17.11 & 4.82 & 201 \\
\hline
\end{tabular}

Table two shows difference in mean scores of male and female students in chemistry post-test. Male students score was 13.51 while that of their female counterparts was 17.11. This shows that female students generally achieved higher than the male students in the post-test. However, the standard deviation for male and female students are 4.00 and 4.82 respectively, indicating that the individual scores of male students are more clustered around the mean than those of their female counterparts.

\subsection{Hypotheses}

$\mathrm{Ho}_{1}$ : There are no significant differences among the mean achievement scores of students taught with discovery-based, problem-based and expository instructional strategies in the chemistry achievement test.

Table 3: Analysis of covariance of students' Mean Achievement scores in chemistry Achievement Test (Teaching Group X Gender)

\begin{tabular}{|l|c|c|c|c|c|c|}
\hline \multicolumn{1}{|c|}{ Source of variation } & Sum of squares & Df & Mean Square & F-Cal. & F-Crit & Remark \\
\hline Corrected model & 3262.459 & 6 & 543.743 & 35.062 & 3.84 & Sig \\
\hline Covariate & 307.420 & 1 & 307.420 & 19.823 & 3.84 & Sig \\
\hline Treatment & 924.293 & 2 & 462.147 & 28.401 & 3.84 & Sig \\
\hline Gender & 1076.647 & 1 & 1076.647 & 70.685 & 3.84 & Sig \\
\hline Treatment Gender & 602.601 & 2 & 301.301 & 19.429 & 3.84 & Sig \\
\hline (2-way interaction) & & & & & & \\
\hline Error & 6746.002 & 435 & 15.508 & & & \\
\hline Total & 112542.00 & 422 & & & & \\
\hline
\end{tabular}

Table 3 shows that the calculated f-value for the effect of treatment on students' achievement in the chemistry test is 28.401 . This is greater than the critical f-value of 3.84 at $2 \mathrm{df}$ for the numerator and 435 for the denominator, at 0.05 level of significance. As such, the null hypothesis is therefore rejected. This mean that there are significant differences in the mean achievement scores of students taught with discovery, problem based and expository learning strategies.

$\mathrm{HO}_{2}$ :There is no significant difference between the mean achievement scores of male and female students in the chemistry achievement test.

Table 3 shows that the calculated f-value for the effect of gender on chemistry taught is 70.685 and $1 \mathrm{df}$ for numerator and 435 for denominator. Since this value (70.685) is greater than the critical f-value of 3.84 at 0.05 level of significance, the null hypothesis is rejected. This means that a significant difference exists in the mean achievement scores of male and female students in the post-test. The difference as shown in table 2 is in favour of female students.

\section{Discussion}

Result of data analysis (Table 1 and 3 ) have shown that students taught with discovery-based and problem-based instructional strategies performed significantly better on the achievement test than their counterparts who were taught using the expository strategy. This result is in agreement with the results of earlier studies carried out by Mayer (2003) and Keislar (2008), both of which 
established the relative efficacy of discovery-based and problem-based instructional strategies in fostering students' achievement in school subjects relative to the expository method. Students taught using problem-based achieved higher than those taught with discovery-based instructional strategy (Table 1) which may well be indicative of the demand each of the method makes of students' learning processes. While the discovery-based instructional strategies suggest that the learner is not provided with the target information or conceptual understanding and must find it independently and only with the provided materials, the problem-based approach avails students of the opportunity to carefully select and design problems that demand from the learner acquisition of critical knowledge, problem solving proficiency, self directed learning strategies and team participation skills (Maloney, 2004). Problem-based strategy reduces teacher's instruction where learners are seen as active listeners and passively involved in classroom activities as in the case of conventional method. More so, problem-based strategy as an example of constructivist learning strategy poses significant contextualized real world situation and provide resources, guidance and instruction to learning as they develop content knowledge and problem solving skills (Yager, 2001).

As indicated in table 2, the mean achievement scores of female students was found to be significantly greater than that of their male counterparts, irrespective of the strategy or methods employed in teaching them the same chemistry topic. It was however, found out that female students in the problem-based group achieved significantly higher than those in the other two groups (discovery-based and expository groups). The observed female superiority in achievement is in line with the findings of studies conducted by Biehler (2003) and Reedy (2001), which established the fact that females are superiority to their male counterparts especially in linguistic and verbal studies. It however differs from the results of studies in Nwagwu (1999), Ibeme (2000), Hutt (2002), which found out that male students achieved significantly higher than female students in sciences and mathematics.

The findings of this study deviated from the already established pattern of male superiority in chemistry achievement. This may be linked to the fact that none of the earlier works cited employed problem-based or discovery-based strategies in the teaching of chemistry and other science subjects. Given by the revelation by Sternberg and Berstein (1998) that no innate difference exist between boys and girls in their intellectual abilities, it may not be surprising to observe, in this study, that female students outperformed their male counterparts in the achievement test.

\section{Conclusion}

The findings of this study show that students taught with problem-based strategy performed significantly better on the chemistry achievement post-test than both the discovery-based and the control (expository) groups.

Also, the mean achievement score of female students was found to be significantly greater than that of their male counterparts irrespective of the instructional strategies used in teaching them same topic in chemistry.

\section{Recommendations}

1. Professional associations and government agencies whose responsibility it is to design and revise the curriculum for secondary schools should incorporate and emphasize the use of problem-based instructional strategy in the teaching of senior secondary certificate (SSC) chemistry .

2. Science teachers should be encouraged to use problem-based instructional strategy in teaching senior secondary school chemistry. The use of problem-based instructional strategy should not be limited to chemistry as a subject, but should be incorporated in other science subjects. 
3. Both male and female students should be exposed to the problem-based teaching method as data available has shown that female students benefit significantly from the study.

\section{References}

Adeyemi, P.A. (2007). Constructivist problem-based learning technique and the academic achievement of physics students with low ability level in Nigeria secondary schools Eurasian. Journal of Physics and Chemistry Education, 1(1), 45-51.

Afolabi F. (2009). The Effects of inquiry-based and competitive learning strategies on academic performance of senior secondary school students in physics. International Journal of Social and Management Sciences (2), 4-10.

Biehler (2003) Sex differences in cognitive abilities. ( $3^{\text {rd }}$ ed.) Lawrence Erlbaum Associates.

Bok, D. (2006). Our underachieving colleges: A candid look at how much students learn and why they should be learning more: Princeton NJ: Princeton University Press.

Bruner, J.S. (1961). Some elements of discovery in Shulman L.S., Keislar, E.R. (Ed.), Learning by discovering: A critical appraisal. Chicago: Rand McNally, pp. 104-111.

Bruner, J.S. (1966). Some elements of discovery. In Shulman L.S., Keislar, E.R. (Ed.), Learning by discovering: A critical appraisal. Chicago: Rand McNally, pp. 104-111.

Bruner, J.S. (1968). Toward a theory of instruction. New York: W.W. Norton and Company.

De Jong, T., \& Van Joolingen, W.R. (1998) Discovering Learning with Computer Simulations of Conceptual Doniains. Review of Educational Research, 68, 179-201.

Domin, A.I. (1999) A review of Laboratory INstructon Styles. Journal with Computer simulations of conceptual doniains. Review of Educational Research, 68, 179-201.

Egbo, J.J. (2004), Effect of concept mapping method of instruction on students' achievement and retention in chemistry. Nigerian Journal of Functional Education 5 (1). Nsukkka: Ephrata Press Production.

Honebein, P. (2006). Seven goals for the design of constructivist Learning environment, New York: Macmillan.

Hutt, C. (2002) Males and Females, London: Pendulum Publishers.

J erkin, R and Dodds K. (2006). Objectives and Instruction. Area Monograph Series. Curriculum Evaluation $3(2), 32-52$.

I beme, V. (2000). "A Study of Sex Differences in Primary School Level. Unpublished B.Sc Thesis. Nsukka UNN.

Kara, Y. \& Ozgun-Coca, S.A. (2004). The Application of Discovering Learning and Meaningful Learning Approaches in Mathematics Classes: Two lesson plans on "the square of addition of two terms". Ikogretim Online 3(1) 2-10.

Keislar, E.R. (2008) Learning by Discovery: A critical appraisal: Chicago: Rand McNally, pp. 104-111.

Kipnis; N. (2005) Chance in Science: The Discovering of Electromagnetism by H.C. Oesrsted; Science \& Education, 14, 1-28.

Mayer, R.E. (2003). Learning and Instruction: Upper Saddle River, N.J: Prentice Hall.

Maloney, D.P. (2004) Research on Problem solving in Physics. In D.L. Gabel (Ed) Handbook of Research in Science Teaching and Learning (Pp. 327-354) New York: Macmillan J ournal of Science Teachers' Association of Nigeria 32(1) 59-64.

Nwabufo, J.N. (2005). Curriculum Implementation and Instructional Plan. Owerri UP Thrust Publishers.

Nwagwu, E.K. (1999). The Development and Standardization of Social Studies achievement tests (SSATS) for J unior Secondary Schools in Anambra State (Unpublished Ph.D. Thesis). University of Nigeria, Nsukkka.

Piaget, J. (1965). "Development and Learning" In Piaget Rediscovered. Washington D.C. National Science Foundation.

Reedy, M.N. (2007). Sex Typing and Socialization. In Mussen, P. (ed) Gr. Michael. Manual of Child Psychology ( $3^{\text {rd }}$ ed.) New York. Wiley.

Urevbu, A. (1990). Methodology of Science Teaching. Benin, Nigeria. Juland Educational.

Sternberg, R.J . and Berstein, A (1998) Testing Common Sense. American Psychologists, 50, 912, 927.

Yager, R.E. (2001), The Constructivist Learning Model Science Teacher 58 (6) 52-57. 
